


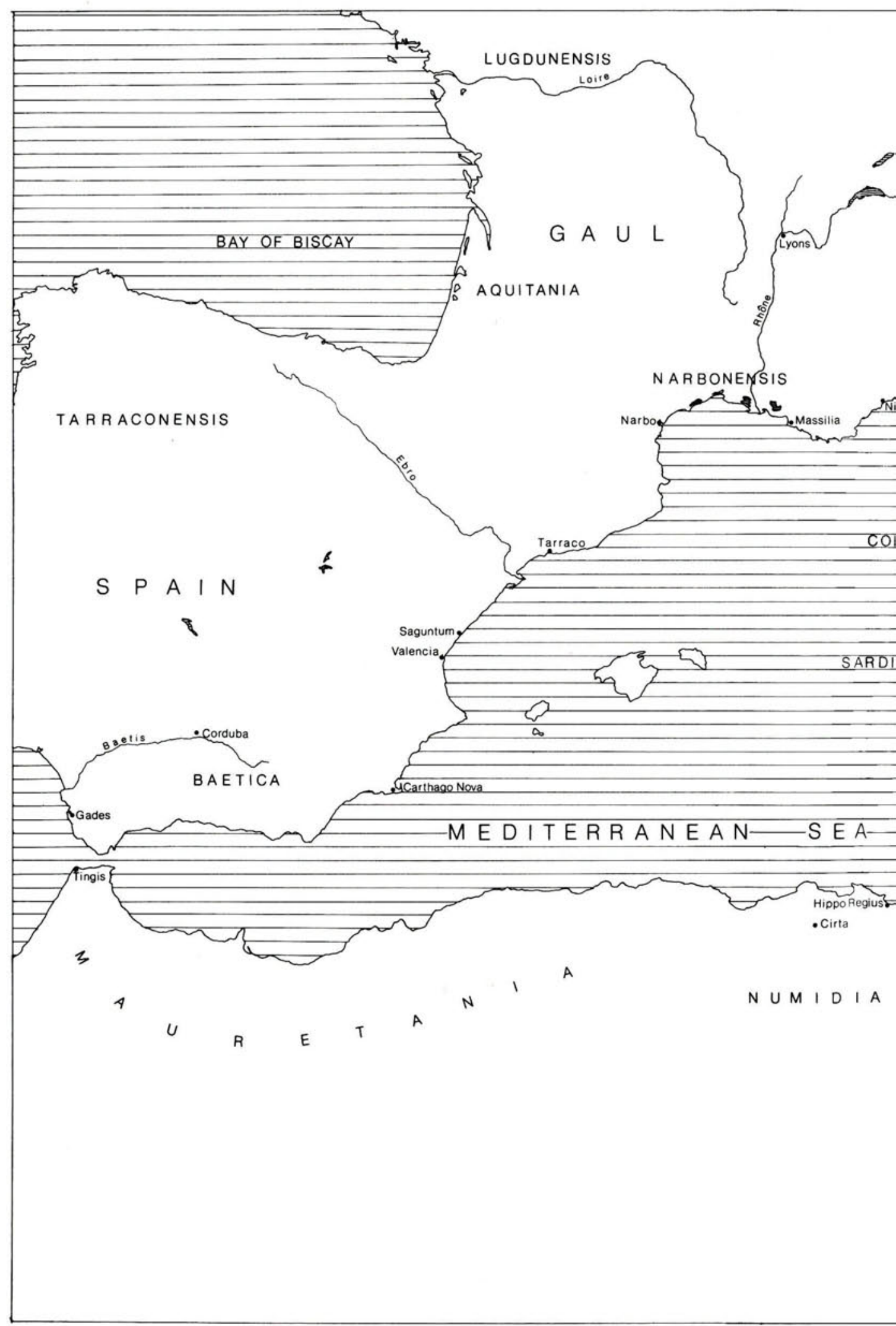



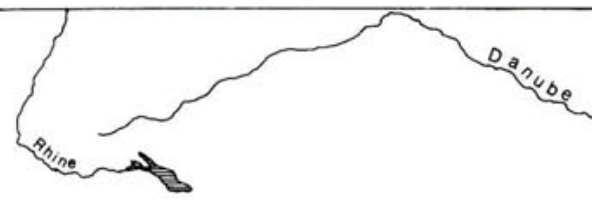

R AETIA

NORICUM PANNONIA
SUPERIOR

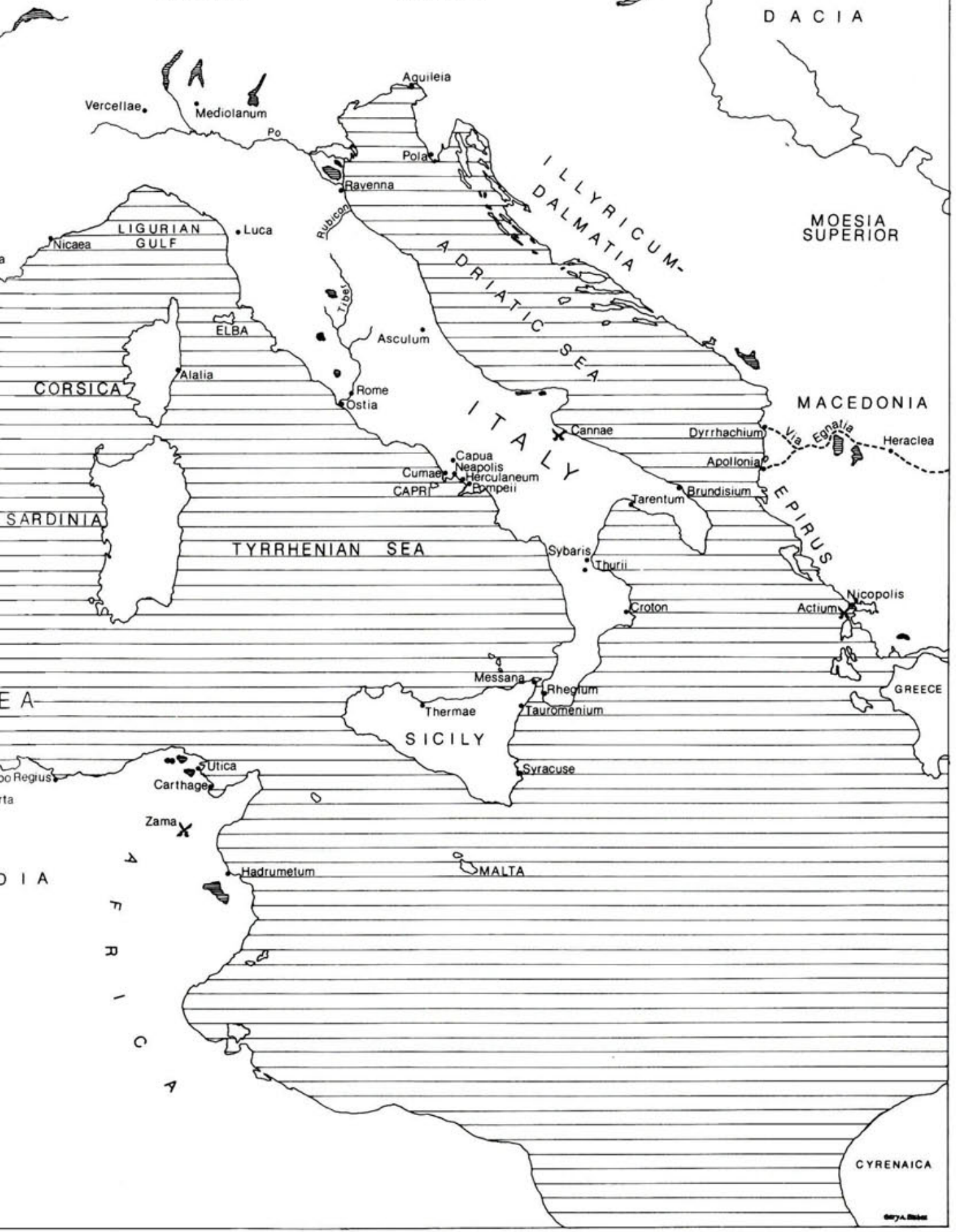



History, Gulture, and Religion of the Hellenistic Age 
Hermeneia

FOUNDATIONS AND FACETS

EdITORIAL BOARD

Helmut Koester, Harvard University, Chairman

Fred O. Francis, Chapman College

Robert W. Funk, University of Montana

James M. Robinson, Claremont Graduate School

EDITOR

Robert W. Funk, University of Montana 
Volume One

INTRODUCTION TO the New Testament

\section{HISTORY, CULTURE, AND RELIGION OF THE HELLENISTIC AGE}

Helmut Koester 
Translated from the German, Einführung in das Neue Testament, Chapters 1-6, by Helmut Köster, copyright $\odot 1980$ by Walter de Gruyter \& Co., Berlin, Federal Republic of Germany, and New York, United States of America.

English translation copyright ${ }^{\odot} 1982$ by Fortress Press, Philadelphia.

All rights reserved. No part of this publication may be reproduced, stored in a retrieval system, or transmitted in any form or by any means, electronic, mechanical, photocopying, recording, or otherwise, without prior permission of the publisher, Fortress Press.

\section{Library of Congress Cataloging in Publication Data}

Koester, Helmut, 1926-

Introduction to the New Testament.

(Hermeneia-foundations and facets)

Translation of: Einführung in das Neue Testament.

Includes bibliographies and indexes.

Contents: v. 1. History, culture, and religion of

the Hellenistic Age-v. 2. History and literature of early Christianity.

1. Bible. N.T.-History of contemporary events.

I. Title. II. Series.

BS2410.K613 $1982 \quad 225.9 ’ 5 \quad 82-71828$

ISBN 0-8006-2100-X (v. 1)

Typeset on an Ibycus System at Polebridge Press 
To The Memory of my Teacher

Rudolf BultManN 
